\title{
Financing Risk of Real Estate Enterprises and Its Prevention and Control Measures
}

\author{
Hongen Guan \\ Inner Mongolia University of Finance and Economics, Hohhot, China \\ Email:469278215@qq.com
}

How to cite this paper: Guan, H.E. (2019) Financing Risk of Real Estate Enterprises and Its Prevention and Control Measures. Open Journal of Business and Management, 7, 1734-1743.

https://doi.org/10.4236/ojbm.2019.74120

Received: August 12, 2019

Accepted: September 22, 2019

Published: September 25, 2019

Copyright $\odot 2019$ by author(s) and Scientific Research Publishing Inc. This work is licensed under the Creative Commons Attribution International License (CC BY 4.0).

http://creativecommons.org/licenses/by/4.0/

\begin{abstract}
Real estate industry has become the pillar industry of the national economy. It needs huge financial support because of its high relevance and high value. At present, the development of real estate financial market in China is slow, which will endanger the sustainable and healthy development of real estate enterprises. Only by effective financing can we improve the market competitiveness of real estate enterprises. This paper expounds the types of financial risks in real estate, analyses the current situation of financing risks in real estate enterprises, and puts forward effective countermeasures to prevent and control financial risks in real estate enterprises.
\end{abstract}

\section{Keywords}

Real Estate Enterprises, Financing Risk Prevention and Control

\section{Introduction}

\subsection{Background}

With the optimization and development of China's real estate industry, it has become an important pillar of the national economy. The real estate industry has contributed a lot to the national economic growth of our country. Real estate-related investment accounts for more than $20 \%$ of China's fixed assets investment. There is a large demand for funds for real estate development projects, which requires a large amount of financial support. At present, facing many risk factors, the development of China's real estate financing market is slow. Effective financing operation can ensure the sustainable and healthy development of the real estate industry. Our government has issued a series of macro-control measures one after another, and implemented strict land policy, which comprehensively regulates and controls housing prices and other details. The single financ- 
ing market pattern of the real estate industry has been seriously impacted, and the diversified financing mode is urgently needed.

\subsection{Significance}

In some developed countries, the financing experience of enterprises has become more mature and perfect after years of development. Our financial institutions and major enterprises are aware of the importance of expanding financing channels, but relevant research is not deep enough. The main perspective is the bank's preventive research on its own financial risk control.

From the perspective of financing of real estate companies, this paper analyses the trend of government policies that affect the financing situation of real estate companies, straightens out the financing methods of real estate companies in China, and puts forward the internal and external risk factors that real estate enterprises are facing in financing. It provides theoretical guidance for the identification and control of financing risk of real estate companies in China. Through the case analysis of financing risk control of real estate enterprises, this paper studies the financial system, identifies the source of risk, provides suggestions on financing risk prevention for the strategic development of the company, and guarantees the company's capital security by changing the way of capital allocation.

\subsection{Research Method}

Through consulting relevant classical literature on financial risk control, this paper makes a theoretical summary to strengthen the theoretical basis of this paper, uses the method of investigation and research to understand the specific situation of real estate companies, and organically combines the content of investigation with the theory of financial risk control, which makes the article put forward specific financial risks for real estate. The control scheme is more operable.

Through quantitative analysis such as financial data analysis, we can accurately understand the current situation of financial risk in enterprises. Qualitative analysis is mainly used to determine the internal and external environmental factors of financial risk in the company, and thoroughly study the control of financial risk in the company. For real estate companies, the financial risk case study object combs and identifies the risk through the financial status quo, and puts forward specific suggestions on financial risk control and prevention.

\subsection{Literature Review}

The developed real estate financial system is the basis of relevant research abroad. The real estate capital market in the United States is the most mature and the largest. The development of real estate financing system in China is quite different from that in other countries. The excellent experience of foreign countries has reference value for the development of real estate financing market 
in China.

By analyzing the cash flow of real estate companies, Crocker H. studied the real estate risk. Ke Suqiang pointed out that real estate securitization is a way of replacing the direct investment of real estate enterprises by securities. Nick mainly studied real estate investment and explored relevant modes to control the real estate financing risk.

The research on real estate financing risk in China started late. Because of the limitations of research conditions, most of the current research on enterprise financing risk control focuses on the theoretical framework stage. Mou Lingling and others divide the real estate investment risk into social risk, technical risk and natural risk, and use the Fuzzy Analytic Hierarchy Process (FAHP) to evaluate the risk, and get the main risk affecting the real estate investment. Wang Yunfeng focuses on the analysis that large-scale financing of real estate using government financing platform is liable to generate greater financial risks, which requires that direct financing channels must be expanded. The existing domestic research results do not have the financial background required by the foreign frontier theory, and there is a lot of room for further research.

\section{Relevant Theory of Financing Risk Control for Real Estate Enterprises}

\subsection{The Concept of Financing Risk of Real Estate Enterprises}

Financing is a process in which funds move from supplier to demander. Financing mainly includes both the demander and supplier of funds, and both sides work together on the flow of funds. Financing is the act of converting activities, such as money lending into instantaneous transactions. Enterprise financing is an economic activity in which enterprises carry out a series of fund operation activities from the perspective of fund demanders and make full use of various financial means, such as securities trading, to fully allocate resources.

According to their development needs, enterprises at different stages of development adopt different development strategies. The starting point for enterprises to adopt financing mode is to facilitate their long-term sustainable and healthy development. In the early stage of entrepreneurship, enterprises cannot afford higher operating costs and banks are reluctant to lend more funds to enterprises. The financing mode of enterprises mainly depends on their own original capital accumulation.

With the continuous improvement of production technology and market share of enterprises, there is an urgent need for a large amount of funds to support the development of enterprises. Banks are willing to carry out related lending business, and enterprises are turning from internal financing to external financing. In the recession stage, the management level of enterprises is gradually declining. Facing the dilemma of internal and external relations, enterprises are in danger [1].

The financing risk of real estate enterprises has the characteristics of expansi- 
bility and controllability. Financial products are involved in every corner of the economy and society. Financial assets are closely related to different financial institutions, and gradually form a network system of mutual influence among asset price fluctuations. In economic exchanges, financial links cannot be separated from the promotion of financial institutions. After the emergence of risks, the rapid transmission of purchased talents through the financial system network leads to the expansion of financial risks.

\subsection{Types of Financing Risks of Real Estate Enterprises}

With the increase of investment in real estate development in China, the main source of funds is bank loans, and the supervision system of real estate financial legal construction is imperfect, resulting in the continuous exposure of enterprise financing problems. At present, China's capital market is not yet perfect. The Chinese Academy of Sciences has monitored more than 240 financing actions of key housing enterprises, and real estate enterprises have more than 3 billion single financing channels. The main risks of real estate financing include operational risk, policy risk and capital turnover risk.

Real estate financing mode is single, and the proportion of real estate enterprises' own capital is low, which cannot reduce the business risk of enterprises. The core of the financial system is to effectively match the financing demand and investment demand. A large number of idle funds have not achieved the optimal investment plan, which leads to the inefficiency of real estate financial funds, the inadequate government supervision mechanism and the lack of credit insurance in China. Many financial products cannot be well promoted and applied. The simplification of enterprise financing increases financial risk. Some super-powerful real estate enterprises get land by high prices, while some small and medium-sized real estate enterprises that need funds cannot get bank credit.

In the securities market, the legislation of real estate enterprises does not adapt to the development of real estate finance. The lack of legal protection of real estate finance, the lack of scientific and standardized operation of real estate financial institutions, and the imperfection of relevant policies lead to the lack of a scientific and effective system of real estate finance, which influences the development of financing channels.

Real estate enterprises cannot obtain bank loans through bank financing deposit banks, which results in real estate enterprises becoming financing market risk-bearing. China has not yet formed a complete financial system, and the efficiency of capital financing is low.

\section{Financing Risk Management of Real Estate Enterprises}

At present, the main problems in real estate financing in China are single financing mode, unreasonable financing structure and imperfect laws and regulations. In the operation of real estate capital, the financing channels are single, and the risk of commercial banks' loan investment market is highly concentrated 
in commercial banks. Direct loans from banks account for more than $60 \%$ of the total capital of real estate enterprises. With the increase of listed financing of real estate enterprises in China, the financing form of bond issuance fades away gradually.

The growth rate of commercial housing investment funds is higher than that of enterprise housing investment. In the investment of real estate enterprises, there is a widespread phenomenon of insufficient capital investment in building affordable housing, which makes the structural imbalance of the real estate market in China and leads to the rupture of the capital circulation chain of enterprises [2].

Because of the imperfection of the relevant laws and regulations of real estate in China, the financing of real estate cannot be promoted smoothly. The government lacks long-term support mechanism for small and medium-sized enterprises, and the construction of real estate legal system lags behind. The legal environment of real estate mortgage law in the Civil Law is imperfect in the actual implementation, which is not conducive to the health of real estate finance.

\section{Establishing Diversified Financing Channels Gradually}

As China's real estate is a capital-intensive industry, with large demand for capital and high risk, China's real estate is facing many problems, such as single financing channels, legal barriers and so on, resulting in excessive pressure on enterprises to repay loans and other hazards. It is necessary to explore a real estate financing model suitable for China's characteristics. According to the current financial risk situation of real estate, in order to effectively control its financial risk within the acceptable range, and fully consider its feasibility, from financing activities, budget management and other aspects, the establishment of financial early warning system puts forward control measures, to the greatest extent, to achieve the effect of pre-control.

\subsection{Achieving Listing Financing}

If real estate enterprises want to survive under the new macro-control environment, they must reasonably choose financial innovation tools to finance. Since 2000, the financing situation of China's real estate market is not optimistic. Many real estate enterprises are seeking overseas listing. Real estate development projects have the characteristics of long payback period and uneven cash flow. The disadvantage of real estate stock market is that it is difficult to be favored by stock investors.

It is very difficult for real estate developers to pass the examination and approval if they want to go public, and most real estate developers can hardly raise funds through direct listing. If they want to go public, they should first meet the requirements of the state for listed companies, evaluate the performance of existing standardized joint-stock enterprises, and invest $70 \%$ of the raised funds in major residential construction. Real estate enterprises should have a good cor- 
porate image in order to attract more investors.

There is no burden of shareholders' interest in listed financing. The company can choose whether to distribute dividends according to its operation. If the company has less surplus or the surplus part has the intention of reinvestment, it cannot distribute dividends. Listed financing institutions raise permanent funds, and the cost of listed financing funds is low, which improves the credit rating of enterprises.

\subsection{Project Financing}

Project financing is mainly based on project assets as collateral, and the financing obtained without recourse is based on the cash flow of the project company itself as the source of repayment. In practical application, the one-time financing amount of the project owner is large. Vanke, Hengda and other benchmark real estate financing amount to 38 billion. Real estate developers use their own capital as equity capital to set up independent project companies, sign financing agreements with financing institutions, and project companies carry out a series of management of project follow-up work, with the future cash flow of development projects as the guarantee for repayment of loans.

The mode of product payment is based on the ownership of the project after putting into production as collateral. It is mainly designed for the method of repayment of project loans. After putting into production, the borrower directly offsets the principal and interest of the project products, and the lender owns the ownership of part of the project products [3].

Arrangement of financing with project as the theme is a prominent feature of project financing, and the main determinant of project sponsor's own creditworthiness and ability fee is the project sponsor's own creditworthiness and ability fee. Investors only assume limited liability for their own debts, and the loan bank can recourse the debts of the investee at a certain stage of its loan. The sponsors of project financing bear part of the risk. Due to the large amount of funds needed in project financing, it is necessary to improve the complex and rigorous guarantee system.

\subsection{Real Estate Investment Trust}

Real estate trust mainly includes real estate fund trust and property trust. Real estate investment trust is an important kind of collective fund trust products launched in China. Trust agencies act as agents for real estate transactions and other escrow business, real estate registration and other matters. The income receipts of the Development Bank of the Real Estate Investment Trust Fund Company collect the investor's capital into a certain range of trust assets, which are handed over to the specialized investment institutions and the financing mode of risk-sharing.

When the free capital of real estate enterprises is less than $35 \%$, some trust and investment companies inject equity capital, which makes the capital of real estate ownership up to $35 \%$. The final return on investment is obtained by the share- 
holders. Bond financing is mainly aimed at the free funds of enterprises meeting the requirements of the state at $35 \%$. In the case of short-term capital difficulties, real estate development enterprises raise funds by directional lending trust and investment companies.

At present, there are obvious differences between real estate trust products and trust products in mature capital market. The characteristics of real estate trust are manifested in the single product model and the gradual emergence of the risk of property use. The risk return of real estate trust has the characteristics of low equity capital. Investors of small and medium-sized real estate projects can take limited liability through investment, and the investment can be arbitrarily divided to overcome the risk of poor liquidity of capital in real estate investment [4].

\subsection{Bond Financing}

Bonds are all kinds of economic entities that aim at raising funds and pay interest periodically at a certain interest rate on bond investment. Bond financing methods often attract the attention of corporate financiers. The amount of bond financing is usually 3 - 10 times that of equity financing. Real estate enterprises obtain the funds needed for development projects by borrowing. Debt financing and credit financing are indirect financing. The requirements for listed financing enterprises are stricter. Bond financing may become the main financing means for real estate enterprises.

The main ways of bond financing in China are corporate bonds, corporate short-term financing bonds and convertible bonds. The Regulations on the Administration of Enterprise Bonds stipulate that the issuance of bonds by enterprises should meet the requirements of the state and have the ability of self-repayment. It has good economic benefits, the purpose of the funds raised conforms to the state regulations, and Article 16 of the Securities Law stipulates that public issuance should conform to the requirements of limited companies, so as to avoid the use of funds to achieve non-productive expenditure.

China's real estate projects have the characteristics of a large amount of funds. In the real estate bond market, corporate bonds cannot be repaid on time. In some factors, it restricts the financing of real estate bonds, which makes it difficult for small and medium-sized real estate enterprises to get involved. The legal system of bond financing of real estate enterprises in China should improve the credit rating system of enterprises and open the principle of access to corporate bond financing. Innovation of bond financing varieties to enhance the ability of enterprises themselves.

\section{Perfecting Real Estate Finance Legislation}

Under the opportunity of financial system reform, according to the actual situation of China's existing real estate finance industry, breaking through the key issues and realizing the distributed management system, the real estate finance legislation can start from two aspects: amending and perfecting the existing laws 
and regulations, and promulgating relevant laws for real estate financing as soon as possible. In view of the "Insurance Law" and other development innovations, it is not suitable for the regulation of real estate finance. In China's Industrial Fund Law, there is legislation concerning enterprise credit, but the financial innovation of real estate cannot be separated from the legal protection, so we should give some government support to effectively dredge the financing channels of enterprises. Local governments should improve the advantages of financing for enterprises and establish loan guarantee institutions to support enterprise financing.

The government should provide certain economic compensation for enterprise financing, increase more financial revenue for national economic development, accelerate the improvement of China's real estate financial legislation activities, and promote the healthy development of real estate enterprises' finance. Enterprises should standardize their internal financial behavior, set up accounts in accordance with the provisions of China's tax law, ensure the legality of tax avoidance, and improve the investment returns of real estate enterprises.

Real estate industry is a high-risk industry. Only by establishing and improving the government support system can we effectively prevent financing risks. The U.S. real estate financial market has established a strong government support system. The government exempts the legal person tax of real estate investment by implementing tax preferential policy, which provides a good external environment for the development of financing methods such as real estate investment fund. China's real estate enterprises should ensure the gradual improvement of the policy support system.

\section{Optimization of Enterprise Management Ability}

In order to avoid the enterprise financing risk, real estate enterprises should attach importance to their own management ability and use less capital flow to promote larger real estate projects. Enterprise financing should also establish corresponding risk guarantee mechanism and gradually withdraw reserve according to business progress. The implementation of risk compensation in enterprise financing makes enterprise financing channels more extensive.

In enterprise management, we should provide efficient and high-quality financial services for enterprises, and formulate and improve loan management strategies effectively. In view of the problem of fund transfer in many real estate enterprises in China, a procedural management process is established to avoid the lack of effective communication in the operation of various departments in real estate enterprises. In view of the disadvantage that a large proportion of funds cannot be withdrawn in time, the Finance Department should assign special personnel to be responsible for financial issues.

Real estate development enterprises generally borrow to raise funds for development and operation. Real estate development enterprises only need to borrow to maintain their development. Corporate debt crisis will endanger the survival of real estate enterprises. Firstly, we should improve the management abil- 
ity of enterprises and the level of managers. In the process of property rights transaction, new capital channels should be expanded and effective internal restraint mechanism should be established to highlight the advantages of capital restructuring.

In the aspect of financing, real estate development enterprises are not only not specialized in financial self-purchase, but also difficult to effectively guard against the technical risks in financing projects. Managers should do a good job of risk aversion plan in the early stage of construction, and do a good job of pre-control measures. In the early stage of construction of a project, a thorough study and comprehensive analysis of bidding documents is conducted to reduce the risk of signing contracts and to prevent unnecessary risks as far as possible. Adjust the contract price in time to reduce the cost risk of the project.

In enterprise financing, expanding financing channels is required to enable enterprises to establish long-term cooperative relations with investors, which can effectively reduce transaction costs. Enterprise financing provides information advantages for enterprise financing, ensures the coordination between financing parties and ensures the economic benefits of enterprises. The expansion of enterprise financing channels should improve the service level of banks to enterprises and eliminate some restrictions of credit policy. Specific credit policies and measures for enterprises should be clarified. Create a favorable environment for enterprises to expand financing channels.

In order to solve the financing problem of real estate enterprises, we should aim at the financing environment of enterprises, improve the financing channels of enterprises, improve the financing efficiency of enterprises, and create the financing mode of enterprises in the new era.

\section{Conclusion}

With the rapid economic development in China, we must attach great importance to the real estate finance risks, and take effective prevention and control measures to ensure the healthy development of real estate enterprises. Financing is an important subject in the field of risk management of real estate enterprises. This paper constructs a comprehensive framework of financing knowledge of real estate enterprises, expounds the risk factors faced by real estate enterprises from macro and micro levels, and expounds the relevant risk prevention and control countermeasures. We should develop individualized financing schemes, establish government support system, and improve their own management capabilities.

\section{Conflicts of Interest}

The author declares no conflicts of interest regarding the publication of this paper.

\section{References}

[1] Li, E.Z. (2018) Discussion on Financing Risk of Real Estate Enterprises. China 
Market, No. 23, $75+81$.

[2] Gao, L. (2018) Research on Financing Risk of Real Estate Enterprises. Accounting Learning, No. 18, 200-201.

[3] Yao, Y.J. (2017) Real Estate Enterprise Financing Risk Analysis and Prevention and Control Strategy Thinking. Times Finance, No. 17, 177.

[4] Wang, J. (2016) Analysis of Financing Risk of Real Estate Development Enterprises and Discussion of Prevention and Control Measures. Accounting of Township Enterprises in China, No. 11, 47-48. 